\title{
Uji Antagonis Actinomycetes terhadap Patogen Colletotrichum capsici Penyebab Penyakit Antraknosa pada Buah Cabai Rawit
}

\author{
Reni Nurjasmi dan Suryani \\ Program Studi Agroteknologi Fakultas Pertanian Universitas Respati Indonesia Jakarta \\ Email: reni_nurjasmi@yahoo.co.id
}

\begin{abstract}
ABSTRAK
Colletotrichum capsici merupakan fungi patogen penyebab penyakit antraknosa pada tanaman cabai. Pengendalian fungi ini umumnya menggunakan fungsida kimia yang justru berdampak negatif bagi lingkungan maupun kesehatan manusia. Pemanfaatan Actinomycetes sebagai pengendali hayati dinilai lebih tepat karena ramah lingkungan. Tujuan penelitian adalah mengetahui kemampuan actinomycetes dalam mengendalikan patogen $C$. capsici penyebab penyakit antraknosa pada buah cabai rawit. Penelitian menggunakan Rancangan Acak Lengkap (RAL). Sampel yang digunakan adalah 9 isolat actinomycetes yang telah diisolasi dari Hutan Pinus Gunung Bunder Bogor dan menghasilkan persentase daya hambat lebih dari $80 \%$ yaitu isolat PnGB1, PnGB4, PnGB6, PnGB9, PnGB10, PnGB11, PnGB14, PnGB16, PngB17 dan kontrol negatif. Setiap perlakuan diulang sebanyak 3 ulangan, sehingga terdapat 30 unit percobaan. Variabel penelitian meliputi masa inkubasi, kejadian penyakit dan intensitas penyakit. Analisis statistik dilakukan dengan menggunakan uji $F$ ANOVA, apabila hasil menunjukkan perlakuan berbeda nyata maka dilakukan uji perbandingan berganda duncan (Duncan's Multiple Range Test). Perlakuan isolat actinomycetes berpengaruh tidak nyata terhadap masa inkubasi dan kejadian penyakit antraknosa pada buah cabai rawit tetapi berpengaruh nyata terhadap intensitas penyakit. Perlakuan PnGB10 merupakan perlakuan yang terbaik dalam menurunkan intensitas penyakit yaitu sebesar $20,05 \%$.
\end{abstract}

Kata kunci: Agen biokontrol, Actinomycetes, Antraknosa, Colletotrichum capsici, Cabai rawit

\begin{abstract}
Colletotrichum capsici is a fungal pathogen that causes anthracnose disease in chili plants. Control of these fungi generally use chemical functions that actually have a negative impact on the environment and human health. Utilization of Actinomycetes as biological controls is considered more appropriate because it is environmentally friendly. The purpose of this study was to determine the ability of actinomycetes in controlling the pathogenic $\mathrm{C}$. capsici that causes anthracnose disease in cayenne pepper. The study used a Completely Randomized Design (CRD). The samples used were 9 actinomycetes isolates that had been isolated from the Gunung Bunder Pine Forest in Bogor and produced a percentage of inhibition of more than 80\%, namely PnGB1, PnGB4, PnGB6, PnGB9, PnGB10, PnGB11, PnGB14, PnGB16, PnGB17 and negative control isolates. Each treatment was repeated 3 replications, so that there were 30 units of the experiment. Research variables include incubation period, disease incidence and disease intensity. Statistical analysis was performed using the ANOVA F test, if the results showed a significantly different treatment then a double comparative test was performed (Duncan's Multiple Range Test). The actinomycetes isolate treatment did not significantly affect the incubation period and the incidence of anthracnose disease in cayenne pepper but it had a significant effect on the intensity of the disease. PnGB10 treatment is the best treatment in reducing the intensity of the disease that is equal to $20.05 \%$.
\end{abstract}

http://ejournal.urindo.ac.id/index.php/pertanian

Article History :

Sumbitted 08 Juni 2020, Accepted 29 Juni 2020, Published 30 Juni 2020 
Key words: Biocontrol agents, Actinomycetes, Anthracnose, Colletotrichum capsici, cayenne pepper

PENDAHULUAN

Komoditas sayuran penting di Indonesia yang memiliki nilai ekonomi tinggi adalah cabai. Permintaan produk cabai terus meningkat seiring dengan meningkatnya jumlah penduduk sehingga sangat potensial untuk tetap dibudidayakan oleh petani. Kebutuhan cabai nasional dalam satu tahun untuk semua kota-kota besar sekitar 800.000 ton per tahun, sedangkan pada hari-hari besar keagamaan kebutuhan cabai biasanya meningkat sekitar $10-20 \%$. Pada budidaya tanaman cabai terdapat beberapa faktor yang dapat menurunkan hasil produksi, salah satunya adalah adanya serangan Organisme Pengganggu Tanaman (OPT) berupa hama, patogen, dan gulma. Penyakit utama yang sering ditemukan pada tanaman cabai merah diantaranya yaitu penyakit antraknosa yang disebabkan oleh fungi patogen Colletotrichum capsici. Patogen ini dapat mengakibatkan kehilangan produksi cabai hingga lebih dari $60 \%$ [1] sehingga sangat merugikan petani apabila tidak segera ditangani.

Penyakit antraknosa pada tanaman cabai menyebabkan kerugian sebesar $60 \%$ bahkan apabila tidak dilakukan pengendalian secara tepat kehilangan hasilnya mencapai $100 \%$. Hal ini mendorong petani untuk menggunakan pestisida secara intensif dengan dosis dan intensitas yang tinggibahkan sebelum ada seranganOPT. Terdapat lebih dari terdapat lebih dari 60 jenis pestisida yang digunakan petani di sentra produksi cabai dengan frekuensi penggunaan berkisar antara 2-3 hari sekali dalam setiap minggu atau sekitar $35-50 \%$ dari total biaya produksi. Penggunaan pestisida secara intensif ini seringkali menimbulkan dampak negatif, baik terhadap lingkungan maupun produk hasil pertanian. Selain itu, penggunaan pestisida kimiawi yang berlebihan dapat menambah biaya produksi dan menyebabkan resistensi OPT. Mengingat besarnya dampak negatif yang ditimbulkan dari penggunaan pestisida kimia maka perlu adanya alternatif lain dalam mengendalikan OPT pada tanaman cabai.

Antraknosa pada cabai adalah penyakit yang paling sering dijumpai dan hampir selalu terjadi di setiap daerah pertanaman cabai. Penyakit ini dapat mengakibatkan penurunan hasil sampai 50 persen lebih. Infeksi pathogen dapat terjadi sejak tanaman di lapangan sampai tanaman dipanen, karena dapat menurunkan produksi baik secara kualitas maupun kuantitas. Pada tingkat serangan yang berat dapat mematikan tanaman. Serangan pada buah dapat mengakibatkan rusaknya buah dan turunnya nilai estetika 
dari buah cabai sehingga nilai ekonomisnya juga rendah [2].

$$
\text { C. capsici dapat menyerang }
$$
sebelum maupun sesudah panen. Organ tanaman yang paling banyak diserang oleh patogen ini adalah buah cabai. Pada awal serangan, tanaman akan menunjukkan gejala bintik-bintik kecil berwarna kehitaman dan sedikit melekuk kemudian buah mengkerut, kering, membusuk dan pada akhirnya jatuh dari pohonnya [3].

Upaya pengendalian penyakit antraknosa yang banyak dilakukan sampai saat ini adalah aplikasi fungisida sintetik. Aplikasi fungisida sintetik dianggap praktis karena mudah didapat dan memberikan efek yang cepat tetapi disamping itu seringkali memberi dampak negatif yaitu meninggalkan residu yang berbahaya, baik terhadap manusia maupun terhadap lingkungan. Alternatif untuk mengurangi penggunaan fungisida sintetik adalah dengan menggunakan fungisida hayati [4]. Upaya pengendalian antraknosa perlu dilakukan untuk mengoptimalkan produktivitas cabai, menekan kehilangan hasil, dan penurunan kualitas buah akibat pemanenan tersebut. Beberapa penelitian telah dilakukan untuk mengendalikan penyakit antraknosa, salah satunya melalui pemanfaatan fungisida hayati yang lebih ramah lingkungan dan tidak berbahaya bagi konsumen, diantaranya adalah actinomycetes [5].
Actinomycetes merupakan agen hayati yang potensial dikembangkan sebagai antifungi. Berbagai jenis actinomycetes telah diisolasi dari berbagai habitat dalam rangka menemukan senyawa antifungi baru, salah satunya adalah Hutan Pinus Gunung Bunder Bogor. Di habitat tersebut telah ditemukan actinomycetes yang berpotensi sebagai penghambat patogen tanaman Fusarium oxysporum dan C. capsici. Namun penelitian yang telah dilakukan sejauh ini baru uji antagonis secara in vitro, oleh karena itu pada penelitian ini akan dilakukan uji antagonis actinomycetes terhadap C. capsici secara in vivo untuk mengetahui kemampuan actinomycetes untuk mengendalikan penyakit antraknosa pada buah cabai rawit. Tujuan penelitian adalah mengetahui kemampuan actinomycetes dalam mengendalikan patogen $C$. capsici penyebab penyakit antraknosa pada buah cabai rawit.

\section{METODE}

\section{Bahan dan Alat}

Alat yang digunakan adalah sentrifus, Laminar air flow, shaker, hotplate, oven, autoklaf, pengaduk kaca, ose, spatula, timbangan digital, cawan petri, mikro pipet, Mikroskop, spektrofotometer, microtip, glass object, cover glass, dan glass ware. Bahan yang digunakan adalah buah cabai rawit umur 3 bulan, isolat 
actinomycetes, isolat C. capsici, Potato Dextrose Agar (PDA), pati, $\mathrm{KNO}_{3}, \mathrm{~K}_{2} \mathrm{HPO}_{4}$, $\mathrm{MgSO}_{4} .7 \mathrm{H}_{2} \mathrm{O}, \mathrm{NaCl}, \mathrm{FeSO}_{4} .7 \mathrm{H}_{2} \mathrm{O}$, agar powder bacteriological, alkohol 70\%, etanol $70 \%$, Tween $80 \%$, kloramfenikol, dan $\mathrm{H}_{2} \mathrm{O}$.

\section{Rancangan Penelitian}

Penelitian ini merupakan penelitian eksperimen, yaitu menguji antagonis actinomycetes dalam mengendalikan penyakit antraknosa pada buah cabai rawit. Rancangan penelitian yang digunakan dalam penelitian ini adalah Rancangan Acak Lengkap (RAL). Pada penelitian ini terdiri dari 9 isolat actinomycetes yang telah diisolasi dari Hutan Pinus Gunung Bunder Bogor dan menghasilkan persentase daya hambat lebih dari $80 \%$ yaitu isolat PnGB1, PnGB4, PnGB6, PnGB9, PnGB10, PngB11, PngB14, PnGB16, PnGB17 dan kontrol negatif. Setiap perlakuan diulang sebanyak 3 ulangan, sehingga terdapat 30 unit percobaan.

Cara Kerja

\subsubsection{Peremajaan Actinomycetes}

Isolat actinomycetes ditumbuhkan pada media Starch Nitrat Agar (SNA) miring dalam tabung reaksi. Selanjutnya diinkubasi pada suhu $32^{\circ} \mathrm{C}$. Isolat murni diremajakan setiap satu sampai dua minggu sekali.

\subsubsection{Peremajaan $C$. capsici}

http://ejournal.urindo.ac.id/index.php/pertanian
Isolat $C$. capsici ditumbuhkan pada media PDA yang sudah ditambahkan antibakteri kloramfenikol. Miselia isolat C.capsici pada tabung reaksi diambil menggunakan ose steril, selanjutnya diletakkan miselia dalam cawan petri yang telah berisi media PDA kemudian diinkubasi selama 7 hari pada suhu ruang.

\subsubsection{Peremajaan Actinomycetes}

Isolat actinomycetes diremajakan pada media SNA. Masing-masing isolat diambil sebanyak satu ose, dan digoreskan pada cawan petri yang berisi media SNA padat. Media yang telah berisi isolat kemudian diinkubasi selama 7 sampai dengan 14 hari pada suhu ruang.

\subsubsection{Pembuatan suspensi $C$. capsici}

Biakan jamur yang telah ditumbuhkan pada media PDA dimasukkan ke dalam erlenmeyer yang berisi $50 \mathrm{ml}$ aquabides steril, kemudian digojog menggunakan shaker incubator selama 6 hari dengan kecepatan 150 rpm pada suhu ruang. Suspensi jamur diambil dengan pipet volumetri dan jumlah konidia dihitung menggunakan spektrofotometer. Apabila jumlahnya terlalu padat maka dilakukan pengenceran sampai diperoleh kerapatan suspensi jamur adalah $1,25 \times 10^{6} \mathrm{sporal} / \mathrm{ml}$.

\subsubsection{Pembuatan suspensi actinomycetes}


Biakan actinomycetes yang telah ditumbuhkan pada media SNA dimasukan ke dalam erlenmeyer $50 \mathrm{ml}$ aquabides steril, kemudian digojog menggunakan shaker incubator selama 7 sampai dengan 14 hari dengan kecepatan 150 rpm pada suhu ruang. Suspensi actinomycetes diambil dengan pipet volumetri dan jumlah sel dihitung menggunakan spektrofotometer. Apabila jumlahnya terlalu padat maka dilakukan pengenceran sampai diperoleh kerapatan actinomycetes adalah $10^{8} \mathrm{cfu} / \mathrm{ml}$.

3.4.6. Pengujian in vivo isolat actinomycetes terhadap $C$. capsici pada buah cabai rawit

Pengujian in vivo mengacu pada metode [6]. Buah cabai disterilisasi pada $\mathrm{NaCl}$ 0,5\% selama 5 menit dan dicuci pada air steril, selanjutnya permukaan buah disterilkan dengan etanol $70 \%$. Selanjutnya buah cabai direndam di dalam suspensi actinomycetes dengan kerapatan $10^{8} \mathrm{cfu} / \mathrm{ml}$ selama 2 jam, selanjutnya ditetesi dengan 0,02\% tween $80 \%(\mathrm{v} / \mathrm{v})$ sebagai penguat penetrasi. Setelah 2 jam dilanjutkan dengan meneteskan suspensi C. capsici sebanyak $20 \mu \mathrm{l}$ dengan kerapatan selnya $1,25 \times 10^{6} \mathrm{konidia} / \mathrm{ml}$ dan $0,02 \%$ tween $80 \%$ (v/v) pada permukaan buah cabai yang sudah dilukai dengan menggunakan jarum ose steril. Seluruh perlakuan diletakkan pada wadah tertutup pada suhu kamar selama 7 hari. Selanjutnya hal-hal yang diamati setelah inkubasi adalah gejala antraknosa yang berupa bercak coklat, kejadian penyakit, dan intensitas penyakit [7].

\subsection{Variabel Penelitian}

a. Masa inkubasi (hari)

Masa inkubasi merupakan waktu yang diperlukan patogen untuk melakukan infeksi, dihitung berdasarkan waktu gejala pertama muncul pada buah cabaisetelah inokulasi. Gejala pada buah cabai berupa bercak kecil dan berair. Ukuran luka tersebut dapat mencapai $3-4 \mathrm{~cm}$ pada buah cabai yang berukuran besar. Pada serangan lanjut yang sudah parah, gejala luka tersebut lebih jelas tampak seperti luka terbakar matahari dan berwarna antara merah tua sampai coklat menyala hingga hitam [8].

b. Kejadian penyakit (\%)[9]:

Kejadian penyakit $=\mathrm{n} \times 100 \%$

$$
\overline{\mathrm{N}}
$$

Keterangan: n: jumlah titik luka yang bergejala; $\mathrm{N}$ : jumlah titik luka yang diamati

c. Intensitas penyakit (\%)[8]:

$$
\text { Intensitas serangan }=\{\Sigma(n \times V)\} \times 100 \%
$$

$$
\text { ZxN }
$$


Keterangan: $\mathrm{n}$ : jumlah buah setiap kelas bercak; V: nilai skor setiap kelas bercak; $\mathrm{N}$ : jumlah buah yang diamati; Z: skor kelas bercak tertinggi

Skor penyakit yang digunakan adalah sebagai berikut :

i. Skor penyakit 0: Tidak ada infeksi

ii. Skor penyakit 1: Luas permukaan

tanaman atau
bagian
tanamanyang
terserang
mencapai 10\%-25\%

iii. Skor penyakit 2: Luas permukaan

tanaman atau
bagian
tanamanyang
terserang lebih
besar dari $25 \%$ -
$50 \%$

iv. Skor penyakit 3: Luas permukaan

tanaman atau
bagian tanaman
yang terserang
lebih besar dari
$50 \%-75 \%$

v. Skor penyakit 4: Tanaman mati

\subsection{Analisa Data}

Analisis statistik dilakukan dengan menggunakan uji F ANOVA, apabila hasil menunjukkan perlakuan berbeda nyata maka dilakukan uji perbandingan berganda duncan (Duncan's Multiple Range Test). Analisis dilakukan pada selang kepercayaan 95\% $(\alpha=0,05)$ menggunakan program SPSS.

\section{HASIL DAN PEMBAHASAN}

\subsection{Pengaruh aplikasi actinomycetes terhadap masa inkubasi penyakit antraknosa pada buah cabai rawit}

Masa inkubasi merupakan waktu yang diperlukan patogen untuk melakukan infeksi dihitung berdasarkan waktu gejala pertama muncul pada buah cabai setelah inkubasi. Semua isolat actinomycetes yang diuji mampu menunda terjadinya gejala serangan $C$. capsici dengan masa inkubasi lebih lama dibandingkan kontrol. Rata-rata masa inkubasi penyakit antraknosa pada buah cabai rawit setelah diberi perlakuan actinomycetes disajikan pada Tabel 1 .

Tabel 1. Pengaruh aplikasi actinomycetes terhadap masa inkubasi penyakit antraknosa pada buah cabai rawit

\begin{tabular}{cc}
\hline Perlakuan & Masa Inkubasi (hari) \\
\hline PnGB1 & $5,50 \mathrm{a}$ \\
PnGB4 & $4,75 \mathrm{a}$ \\
PnGB6 & $5,10 \mathrm{a}$
\end{tabular}




\begin{tabular}{clll} 
PnGB9 & $5,20 \mathrm{a}$ & \\
PnGB10 & $5,75 \mathrm{a}$ & \\
PnGB11 & $4,75 \mathrm{a}$ & \\
PnGB14 & $5,50 \mathrm{a}$ & \\
$5,00 \mathrm{a}$ & \\
PnGB16 & $4,75 \mathrm{a}$ & \\
PnGB17 & $4,25 \mathrm{a}$ & \\
Kontrol & & & \\
\hline Keterangan: & Angka-angka yang diikuti oleh huruf yang sama pada kolom \\
& menunjukkan berbeda tidak nyata dengan menggunakan uji lanjut \\
& Duncan pada taraf 5\%
\end{tabular}

Aplikasi actinomycetes sebagai agen biokontrol secara in vivo mampu mengurangi serangan penyakit antraknosa. Gejala awal penyakit antraknosa pada buah cabai berupa titik kecil berwarna kehitaman yang lama-kelamaan membesar dan membentuk lekukan. Pada lekukan tersebut terdapat struktur berwarna kehitaman yang disebut seta yang merupakan ciri khas $C$. capsici. Gejala lebih lanjut dari penyakit antraknosa menyebabkan buah menjadi kering dan keriput.

Dari uji patogenisitas, gejala awal serangan penyakit antraknosa ditandai dengan timbulnya bercak berwarna merah kehitaman pada permukaan cabai. Bercak tersebut kemudian melebar dan berubah warna menjadi hitam pada bagian tengah cabai. Gejala serangan antraknosa diawali dengan adanya bintik kecil berwarna kehitaman dan berlekuk [10]. Gejala penyakit antraknosa oleh jamur Colletotrichum capsici pada buah cabai adalah berupa bercak cokelat kehitaman, kemudian meluas menjadi busuk lunak dan pada bagian tengah bercak terdapat titiktitik hitam [11].

Masa inkubasi merupakan periode waktu yang dibutuhkan patogen sejak pertama terjadi kontak hingga timbul infeksi yang diperlihatkan melalui gejala yang muncul pada buah cabai. Berdasarkan pengamatan gejala patogen antraknosa pada buah cabai rawit yakni berupa timbulnya cekungan berwarna coklat tua yang semakin hari semakin membesar pada permukaan buah [12]. Buah cabai merah besar yang terserang antraknosa menunjukkan gejala berupa timbulnya cekungan yang membesar pada permukaan buah dan pada bagian tengah cekungan terrdapat kumpulan titik-titik hitam yang merupakan kelompok aservulus [13] .

\subsection{Pengaruh aplikasi actinomycetes terhadap kejadian penyakit antraknosa pada buah cabai rawit Gejala awal penyakit antraknosa adalah bercak kecil seperti tersiram air}


dengan warna bercak kehitaman pada permukaaan buah yang terinfeksi kemudian menjadi busuk lunak. Ekspansi bercak yang maksimal membentuk lekukan dengan berwarna merah gelap. Serangan yang berat menyebabkan seluruh buah keriput dan mengering. Gejala segera nampak berupa titik gelap, sedikit cekung dan bergaris tengah $4 \mathrm{~mm}$. Bercak akan segera berkembang hingga mencapai seluruh permukaan buah. Patogen dapat menginfeksi buah melalui luka maupun secara langsung. Sedangkan keadaan yang basah dan adanya air hujan sangat berperan dalam penyebaran spora dari satu tanaman ke tanaman lain [14].

Kejadian penyakit pada perlakuan isolat actinomycetes seperti yang disajikan pada Tabel 2. Perlakuan filtrat actinomycetes tidak sepenuhnya mampu menghambat perkembangan C. capsici, yang ditandai dengan adanya bercak pada buah cabai pada setiap perlakuan. Hal ini disebabkan karena adanya pelukaan saat inokulasi patogen sehingga memungkinkan patogen berkembang sebelum dihambat oleh filtrat yang kuat, sehingga kejadian penyakit antraknosa pada buah cabai terjadi pada semua perlakuan dengan tingkat kejadian penyakit $100 \%$.

Kejadian penyakit sangat baik untuk dijadikan referensi dari sisi ekonomi karena memperhitungkan seberapa besar kehilangan buah dari serangan antraknosa. Kejadian penyakit menunjukkan parameter terbaik untuk dijadikan tolak ukur klasifikasi tingkat ketahanan [15].

Tabel 2. Pengaruh aplikasi actinomycetes terhadap kejadian penyakit antraknosa pada buah cabai rawit

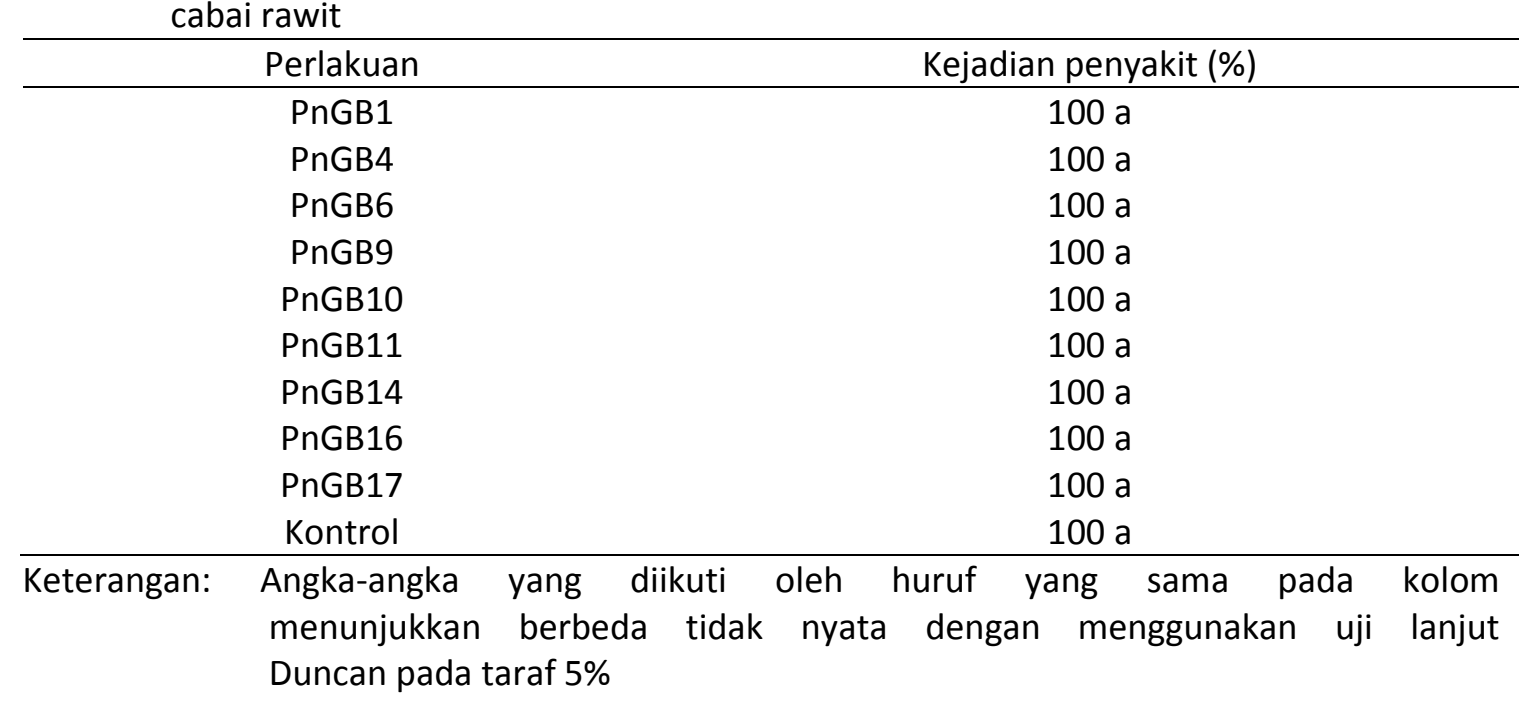

4.3. Pengaruh aplikasi actinomycetes terhadap intensitas penyakit antraknosa pada buah cabai rawit

http://ejournal.urindo.ac.id/index.php/pertanian
Berdasarkan hasil sidik ragam aplikasi actinomycetes pada buah cabai menunjukkan hasil berbeda nyata dalam 
menekan intensitas penyakit antraknosa. Tabel 3 menunjukkan bahwa semua isolat actinomycetes memiliki kemampuan menghambat penyakit antraknosa pada buah cabai rawit yang ditunjukkan oleh intensitas penyakit antraknosa pada buah cabai yang diaplikasikan actinomycetes lebih rendah dibandingkan kontrol. Perlakuan PnGB10 menunjukkan tingkat intensitas paling rendah $(20,05 \%)$ dan berbeda nyata pada setiap perlakuan kecuali PnGB1 $(27,45 \%)$.

Penghambatan gejala antraknosa yang disebabkan oleh actinomycetes diduga akibat adanya mekanisme kompetisi nutrisi dan ruang serta parasitisme. Pelukaan buah yang dibuat untuk inokulasi patogen dimanfaatkan oleh actinomycetes untuk memperoleh nutrisi serta mampu mengkolonisasi permukaan buah dengan cepat dibandingkan dengan C. capsici. Isolat actinomycetes diduga menghasilkan enzim litik serta memiliki mekanisme hiperparasitisme terhadap $C$. capsici. Oleh karena itu, isolate actinomycetes memiliki potensi untuk menggantikan fungisida kimia.

Strategi umum pengendalian hayati adalah menggunakan organisme hidup sebagai agen pengendalian hayati penyakit prapanen dan pascapanen pada buah-buahan dan sayuran. Pengendalian penyakit pascapanen lebih efektif dan efisien daripada pengendalian prapanen [16].

Perlakuan filtrat isolat Actinomycetes PnGB10 menunjukkan aktivitas penghambatan yang paling kuat terhadap $C$. capsici dengan luas bercak terendah dibandingkan dengan isolat lainnya, hal itu dikarenakan isolat tersebut melalui mekanisme antagonisnya mampu mengurangi jumlah inokulum awal jamur patogen.

Metode pengendalian dengan mikroba antagonis terhadap Colletotrichum bertujuan untuk mengurangi infeksi awal. Senyawa yang dihasilkan oleh bakteri antagonis dapat menghambat perkecambahan konidia dan penyerapan nutrisi yang dibutukan patogen untuk berkembang. Meskipun penetrasi telah berhasil dilakukan oleh jamur patogen, tetapi sebelum infeksi berkembang, pertumbuhan hifa dihambat oleh antibiotik atau enzim litik yang dihasilkan oleh mikroba, sehingga menyebabkan pengurangan perkembangan bercak nekrosis [17].

Tabel 3. Pengaruh aplikasi actinomycetes terhadap intensitas penyakit antraknosa pada buah cabai rawit

\begin{tabular}{cc} 
cabai rawit & Intensitas Penyakit (\%) \\
\hline Perlakuan & 27,45 bc
\end{tabular}




\begin{tabular}{ccc} 
PnGB4 & $86,30 \mathrm{a}$ & \\
PnGB6 & $77,65 \mathrm{a}$ & \\
PnGB9 & $75,20 \mathrm{ab}$ & \\
PnGB10 & $20,05 \mathrm{c}$ & \\
PnGB11 & $82,65 \mathrm{a}$ & \\
PnGB14 & $76,20 \mathrm{ab}$ & \\
PnGB16 & $68,80 \mathrm{ab}$ & \\
PnGB17 & $87,65 \mathrm{a}$ & \\
Kontrol & $100,00 \mathrm{a}$ & \\
\hline Keterangan: & Angka-angka yang diikuti oleh huruf yang sama pada kolom \\
& menunjukkan berbeda tidak nyata dengan menggunakan uji lanjut \\
& Duncan pada taraf 5\% d
\end{tabular}

Perlakuan filtrat isolat actinomycetes lainnya memperoleh hasil yang kurang optimal dalam mengurangi intensitas penyakit. Hal ini diduga dikarenakan kandungan senyawa antibiotiknya kurang optimum, sehingga kurang efektif dalam mengendalikan jamur $C$. capsici. Selain itu, permukaan buah yang licin diduga berpengaruh terhadap keefektifan filtrat dalam menekan pertumbuhan jamur patogen, sehingga tidak sepenuhnya filtrat mampu mengurangi infeksi patogen.

Perlakuan filtrat $P$. fluorescens isolat actinomycetes PnGB10 paling efektif mengurangi intensitas penyakit jika dibandingkan dengan perlakuan lainnya,

\section{SIMPULAN}

Kesimpulan penelitian adalah penggunaan actinomycetes sebagai agen biokontrol dalam uji in vivo dapat menekan masa inkubasi, kejadian penyakit dan intensitas penyakit antraknosa pada buah cabai rawit. Perlakuan PnGB10 merupakan

http://ejournal.urindo.ac.id/index.php/pertanian diduga senyawa yang dihasilkan lebih efektif dalam mengurangi jumlah inokulum awal, yang menyebabkan spora tidak mampu untuk berkembang. Hal ini menyebabkan terhambatnya proses pembentukan dinding sel yang diperlukan untuk memanjangkan ujung hifa, percabangan dan pembentukan spora, menghambat pembentukan tabung kecambah (germinasi) dan pertumbuhan miselium, menghambat atau mengganggu permeabilitas membran sel jamur, sehingga patogen tidak mampu melakukan proses infeksi selanjutnya [18].

perlakuan yang terbaik dalam menurunkan intensitas penyakit yaitu sebesar $20,05 \%$.

\section{DAFTAR PUSTAKA}

[1] Sektiono, A.W., S.N. Kajariyah, dan S. Djauhari. 2016. Uji Antagonisme 
Actinomycetes Rhizosfer dan Endofit Akar Tanaman Cabai (Capsicum Frutescens L.) terhadap Jamur Colletotrichum Capsici (Syd.) Bult Et Bisby. Jurnal HPT, 4 (1), Januari 2016. ISSN : $2338-4336$.

[2] Nurhayati. 2011. Efetivitas Ekstrak Daun Sirih terhadap Infeksi Colletotrichum Capsici pada Buah Cabai. Dharmapala, Volume 3, No. 2. Fakultas Pertanian, Universitas Sriwijaya, Sumatera Selatan.

[3] Rusli, I., Mardinus dan Zulpadli. 1997. Penyakit Antraknosa pada Buah Cabai Di Sumatera Barat. Prosiding Kongres Nasional XVI Perhimpunan Fitopatologi Indonesia, Palembang.

[4] Elfina, Y., M. Ali dan L. Aryanti. 2015. Uji Beberapa Konsentrasi Ekstrak Tepung Daun Sirih Hutan (Piper Aduncum L.) Untuk Mengendalikan Penyakit Antraknosa Pada Buah Cabai Merah Pasca Panen. SAGU Vol. 14 No. 2 : 18-27. Fakultas Pertanian, Universitas Riau, Pekanbaru.

[5] Wilia W. 2010. Potensi Cendawan Endofit dan Khamir untuk Mengendalikan

Penyakit Antraknosa (Colletotrichum Acutatum L.) pada Tanaman Cabai [Tesis]. Institut Pertanian Bogor.

[6] Dan H, X. D. Zheng, Y.M. Yin , P. Sun., dan H.Y. Zhang . 2003. Yeasts Application For Controlling Apple
Postharvest Diaseases Associated with Pennicillium Expasum Bot. Bull. Acad. Sin.Vol. 44 : 211-216.

[7] Marlina, Hafsah, dan Siti. R. 2012. Efektivitas Lateks Pepayat Perkembangan Colletotrichum Capsici pada Buah Cabai . Jurnal Penelitian Universitas Jambi Seri Sainsvol.14. No.1

[8] Syabana, M. A. Saylendra, A., dan Ramadhani, D. 2015. Aktivitasanti Cendawan Ekstrak Daun Sereh Wangi (Cymbopogan Nardus) terhadap Colletotrichum sp. Penyebab Penyakit Antraknosa pada Buah Cabai (Capsicum Annum) Secara In Vitro dan In Vivo: Agrologia, Vol.4, No.1 April 2015.

[9] Handayani, R. M. 2016. Potensi Cendawan Endofit Dalam Upaya Pengendalian Penyakit Antraknosa (Colletotrichum Capsici) pada Tanaman Cabai Merah. Skripsi. Institut Pertanian Bogor.

[10] Semangun H. 2000. Pengantar IImu Penyakit Tumbuhan. Yogyakarta. Gadjah Mada University Press.

[11] Novizan. 2002. Reaksi Beberapa Kultivar Buah Lombok Besar (Capsicum Annuum L.) terhadap (Colletotrichum Capsici). Risalah Seminar Perhimpunan Fitopathologi Indonesia VIII. Cibubur, Jakarta, Okt. 
[12] Harmaningrum, N.W. 2015. Peningkatan Potensi Agen Hayati untuk Mengendalikan Penyebab Penyakit Antraknosa (Colletotrichum Sp.) pada Tanaman Cabe Jawa (Piper Retrofractum Vahl.) Melalui Penambahan Bahan Organik [Skripsi] . Universitas Jember.

[13] Nayaka, S.C., Shankar, A.C.U., Niranjana, S.R., Prakash, H.S., dan Mortensen, C.N. (2009). Anthracnose Disease of Chilli Pepper. Technical Bulletin.

[14] Zen, K., R. Setiamihardja, Murdaningsih, dan T. Suganda. 2002. Aktivitas Enzim Peroksidase pada Lima Genotip Cabai yang Mempunyai Ketahanan Berbeda Terhadap Penyakit Antraknosa. Jurnal Agronomi. Zuriat 13(2):97-105.

[15] Purwati, E., B. Jaya., dan A. S. Duriat. 2000. Penampilan Beberapa Varietas Cabai dan Uji Resistensi Terhadap
Penyakit Virus Kerupuk. Jurnal Hortikultura. 10(2):88-94.

[16] Dharmaputra, O. S., Lisdar, I. S., dan Maria, M. M. 2016. Potensi Khamir sebagai Agens Pengendalian Hayati Colletotrichum Capsici, Cendawan Penyebab Antraknosa pada Buah Cabai. J. Hort. Indonesia 7(2): 91-101.

[17] Jeffries, P. dan I. Koomen. 1992. Strategies dan Prospects for Biological Control of Diseases Caused by Colletotrichum. In J. A. Bailey dan M. J Jeger (Eds.) Colletotrichum Biology, Pathology and Control. CAB Internasional 337-357.

[18] Compant, S., B. Duffy, J. Nowak, C. Cle'Ment. dan E. D. A. Barka. 2005. Use of Plant Growth-Promoting Bacteria for Biocontrol of Plant Diseases: Principles, Mechanisms of Action, and Future Prospects. Applied and Environmental Microbiology 72(9): 4949-4959. 